\title{
NEW DISTRIBUTION DATA OF THE VULNERABLE MERTENSIELLA CAUCASICA FROM GÜMÜSSHANE, TURKEY
}

\author{
Muammer Kurnaz*, Bilal Kutrup \\ Karadeniz Technical University, Turkey \\ *e-mail:mkurnaz@ktu.edu.tr
}

Received: 06.11.2018. Revised: 08.01.2019. Accepted: 12.01.2019.

\begin{abstract}
The Caucasian salamander, Mertensiella caucasica, is a vulnerable species, distributed in a restricted area from the southwest of Georgia to the northeast of Turkey. This study presents five new localities from the Gümüşhane province in Turkey. The new localities extent the known distribution by about $40 \mathrm{~km}$ southwards. We determine the species' potential distribution in this province. The habitat of $M$. caucasica has been predicted to shrink in the future and localities on the range boundary such as presented here will be important to understand the species' tolerance.
\end{abstract}

Key words: Caucasian salamander, environmental variable, habitat preference, potential distribution, range extension, southernmost locality

The Caucasian salamander Mertensiella caucasica (Waga, 1876) belongs to a monotypic genus (Veith et al., 1998; Üzüm, 2009). It is distributed in a small area in the Lesser Caucasus, from southwestern Georgia to northeastern Turkey (Baran \& Atatür, 1998; Üzüm, 2009; Baran et al., 2012). Because the population of the species is decreasing, it is classified as Vulnerable (VU) by the IUCN Red List of the Threatened Species (Kaya et al., 2009). Not many localities are known from this species in literature. Several studies have been performed on its taxonomy, morphology, distribution and ecology (Tarkhnishvili \& Serbinova, 1992; Veith et al., 1998; Tarkhnishvili et al., 2000, 2008; Veith \& Steinfartz, 2004; Sayım et al., 2009; Üzüm, 2009; Baran et al., 2012; Beşer et al., 2017; Gül et al., 2017, 2018). We compiled a distribution database for the Caucasian salamander from the Province of Gümüşhane in Turkey at the most western extreme of the species' range and we determined its potential distribution with the present study.

Until now five localities were known from the Province of Gümüşhane in Turkey (Atatür \& Budak, 1982; Beşer et al., 2017; Gül et al., 2017). The present study reports five new localities recorded during field studies in this province in the period 24-31 August 2012 (Table 1). The new localities represent a ca $40 \mathrm{~km}$ range extension. After the specimens of $M$. caucasica were photographed, and GPS data were recorded, they were released again; no specimens were collected.

To create a species distribution model for $M$. caucasica in the Province of Gümüşhane, 19 bioclimatic data layers were downloaded from Global Climate Data (available at www.worldclim.org). These data were generated from global ESRI grids at the highest resolution (30 arc-seconds $(\sim 1 \mathrm{~km})$ ) for current conditions $(\sim 1950-2000)$. For the elevation, the SRTM30 dataset from CGIARSRTM, aggregated to 30 sec., was used (available at http://srtm.csi. cgiar.org/). Slope data were downloaded from http:// webarchive.iiasa.ac.at/ with a 30 arc-second resolution. ArcToolbox was used to cut layers according to the country border of Turkey (extract by mask). ENMTools 1.4 (Warren et al., 2010) was used to identify a subset of data layers with a Pearson correlation coefficient of $0.75<\mathrm{r}<-0.75$ (Table 2).

Maxent 3.3.3k (Phillips et al., 2006) was used to perform species distribution modelling. To develop the model, five occurrence data from the literature as well as the five new locality records were used. $25 \%$ of the occurrence data were set aside as test points, and 10.000 background points were used as pseudoabsence data. Additional settings in Maxent were: regularization multiplier $=0.5$, maximum iterations $=500$, convergence threshold $=0.00001$. To test the variable importance, a jackknife test was conducted in Maxent, and ten replicates of the were run.

Table 1. Occurrence data of Mertensiella caucasica in Gümüşhane

\begin{tabular}{cccc}
\hline Latitude & Longitude & References & Locality \\
\hline 40.560937 & 40.058291 & Atatür \& Budak, 1982 & Güngören \\
40.655866 & 39.400910 & Atatür \& Budak, 1982 & Zigana \\
40.594266 & 39.152421 & Gül et al., 2017 & Demirkapı \\
40.587152 & 39.332630 & Gül et al., 2017 & Soğuksu \\
40.533333 & 38.916667 & Beşer et al., 2017 & Kazıkbeli Yaylası \\
40.470933 & 39.288383 & This study & Altınpınar \\
40.385133 & 39.125700 & This study & Gülaçar \\
40.391317 & 39.141483 & This study & Gülaçar \\
40.349300 & 39.174983 & This study & Kocadal \\
40.290583 & 39.250183 & This study & Kocadal \\
\hline
\end{tabular}


Table 2. Relative contribution of climate layers to the distribution model of Mertensiella caucasica

\begin{tabular}{|l|c|}
\hline \multicolumn{1}{|c|}{ Variable } & \multicolumn{1}{|c|}{$\begin{array}{c}\text { Percent } \\
\text { contribution (\%) }\end{array}$} \\
\hline $\begin{array}{l}\text { Bio 10 (Mean Temperature of } \\
\text { Warmest Quarter) }\end{array}$ & 26.9 \\
\hline $\begin{array}{l}\text { Bio 18 (Precipitation of Warmest } \\
\text { Quarter) }\end{array}$ & 23.5 \\
\hline $\begin{array}{l}\text { Bio 8 (Mean Temperature of Wettest } \\
\text { Quarter) }\end{array}$ & 18.6 \\
\hline $\begin{array}{l}\text { Bio 6 (Min Temperature of Coldest } \\
\text { Month) }\end{array}$ & 11.0 \\
\hline Slope & 9.8 \\
\hline Bio 13 (Precipitation of Wettest) & 5.4 \\
\hline $\begin{array}{l}\text { Bio 5 (Max Temperature of Warmest } \\
\text { Month) }\end{array}$ & 2.5 \\
\hline $\begin{array}{l}\text { Bio 19 (Precipitation of Coldest } \\
\text { Quarter) }\end{array}$ & 2.4 \\
\hline
\end{tabular}

According to the species distribution model, suitable habitat for the species is present in north and central Gümüşhane, but not the south (Fig. 1). The environmental variables that contributed most to the species distribution model were Bio 10 (26.9\%), Bio 18 (23.5\%) and Bio 8 (18.6\%) (Table 2). Bio 10 presented the most useful information when used by itself in Maxent. According to the jackknife analysis, the performance of the model was lowest without Bio 10. The final constructed species distribution models resulted in a high AUC value with a low standard deviation $(0.997 \pm 0.003)$.

According to the literature, the Caucasian salamander, M. caucasica, was only known from the north of the Gümüşhane province in Turkey (Atatür \& Budak, 1982; Beşer et al., 2017; Gül et al., 2017). Our new localities show that the species is distributed further southwards. This is further supported by our species distribution model (Fig.). Climate conditions are one of the main factors that restrict species distributions (Cahill et al., 2013). Mertensiella caucasica is adapted to the Caucasus biodiversity hot spot climate (Tarhnishvili et al., 2000). In the present study, we found that at the margin of its range in Gümüşhane province the most important variables affecting the distribution of $M$. caucasica are Mean Temperature of Warmest Quarter (Bio 10), Precipitation of Warmest Quarter (Bio 18), and Mean Temperature of Wettest Quarter (Bio 8). According to Gül et al. (2018) the potential habitat of $M$. caucasica will shrink under future climate scenarios. Populations at range margins are important to assess the tolerance of the Caucasian salamander.

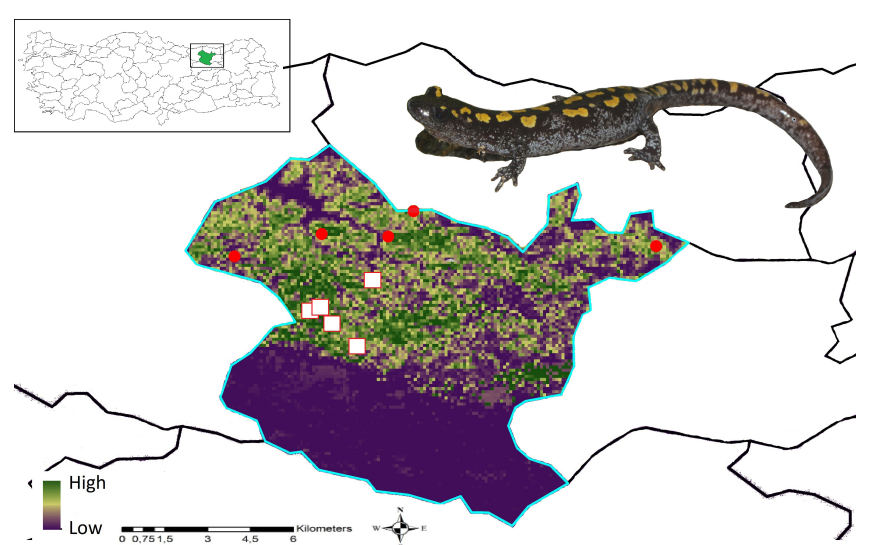

Fig. The potential distribution and habitat suitability of the Caucasian Salamander (Mertensiella caucasica) in Gümüşhane. Colours represent habitat suitability (see scale bar). Red circles: localities from the literature. White squares: localities newly reported in the present study.

\section{References}

Atatür M.K., Budak A. 1982. The present study of Mertensiella caucasica (Waga, 1876) (Urodela: Salamandridae) in Northeastern Anatolia. Amphibia-Reptilia 3(4): 295 301. DOI: 10.1163/156853882X00013

Baran İ., Atatür M.K. 1998. Turkish Herpetofauna (Amphibians and Reptiles). Ankara: Ministry of Environment. 214 p. [In Turkish]

Baran İ., Ilgaz Ç., Avcý A., Kumlutaş Y., Olgun K. 2012. Türkiye Amfibi ve Sürüngenleri, Tübitak Popüler Bilim Kitaplarý. Vol. 207, Ankara, Turkey: Tübitak. [In Turkish]

Beşer N., Avcı A., Ilgaz Ç., Tuniyev S.B., Tuniyev B.S., Üzüm N. 2017. Age structure and body size of Mertensiella caucasica (Waga, 1876) (Caudata: Salamandridae) in a population from Turkey. Russian Journal of Herpetology 24(3): 202-208.

Cahill A.E.; Aiello-Lammens M.E., Fisher-Reid M.C., Hua X., Karanewsky C.J., Ryu H.Y., Sbeglia G.C., Spagnolo F., Waldron J.B., Warsi O., Wiens J.J. 2013. How does climate change cause extinction? Proceedings of the Royal Society of London B: Biological Sciences 280(1750): 20121890. DOI: 10.1098/rspb.2012.1890

Gül S., Candan K., Kumlutaş Y. 2017. Two new records of the Caucasian salamander (Mertensiella caucasica Waga, 1876) located in the northeast Anatolia mountains. Tabiat ve Insan 199: 22-25.

Gül S., Kumlutaş Y., Ilgaz Ç. 2018. Potential distribution under different climatic scenarios of climate change of the vulnerable Caucasian salamander (Mertensiella caucasica): A case study of the Caucasus Hotspot. Biologia 73: 175-184. DOI: 10.2478/s11756-018-0020-y

Kaya U., Tuniyev B., Ananjeva N., Orlov N., Papenfuss T., Kuzmin S., Tarkhnishvili D., Tuniyev S., Sparreboom M., Ugurtas İ.H., Anderson S. 2009. Mertensiella caucasica. In: The IUCN Red List of Threatened Species 2009: e.T13198A3418986. Available from: http://dx.doi. org/10.2305/IUCN.UK.2009.RLTS.T13198A3418986.en

Phillips S.J., Anderson R.P., Schapire R.E. 2006. Maximum entropy modeling of species geographic distribu- 
tions. Ecological Modelling 190(3-4): 231-259. DOI: 10.1016/j.ecolmodel.2005.03.026

Sayım F., Başkale E., Tarkhnishvili D., Kaya U. 2009. Some water chemistry parameters of breeding habitats of Caucasian salamander, Mertensiella caucasica in the Western Lesser Caucasus. Comptes Rendus Biologies 332(5): 464-469. DOI: 10.1016/j.crvi.2009.01.001

Tarkhnishvili D.N., Serbinova I.A. 1992. The ecology of the Caucasian Salamander (Mertensiella caucasica Waga) in a local population. Asiatic Herpetological Research 5: 147-165.

Tarkhnishvili D.N., Trophe R.S., Arntzen J.W. 2000. PrePleistocene refugia and differentiation between populations of the Caucasian Salamander (Mertensiella caucasica). Molecular Phylogenetics and Evolution 14(3): 414-422. DOI: 10.1006/mpev.1999.0718

Tarkhnishvili D.N, Kaya U., Gavashelishvili A., Serbinova I. 2008. Ecological divergence between two evolutionary lineages of the Caucasian salamander: Evidence from the GIS analysis. Herpetological Journal 18: 155-163.
Üzüm N. 2009. A skeletochronological study of age, growth and longevity in a population of Caucasian Salamander, Mertensiella caucasica (Waga, 1876) (Caudata: Salamandridae) from Turkey. North-Western Journal of Zoology 5(1): 74-84.

Warren D.L., Glor R.E., Turelli M. 2010. ENMTools: a toolbox for comparative studies of environmental niche models. Ecography 33(3): 607-611. DOI: 10.1111/j.1600-0587.2009.06142.x

Veith M., Steinfartz S., Zardoya R., Seitz A., Meyer A. 1998. A molecular phylogeny of 'true' salamanders (Family Salamandridae) and evolution of terrestriality of reproductive modes. Journal of Zoological Systematic and Evolutionary Research 36(1-2): 7-16. DOI: 10.1111/ j.1439-0469.1998.tb00774.x

Veith M., Steinfanrtz S. 2004. When non-monophyly results in taxonomic consequences - the case of Mertensiella within the Salamandridae (Amphibia: Urodela). Salamandra 40(1): 67-80.

\title{
НОВЫЕ ДАННЫЕ О РАСПРОСТРАНЕНИИ MERTENSIELLA CAUCASICA ИЗ ГЮМЮШХАНЕ (ТУРЦИЯ)
}

\author{
М. Курназ", Б. Кутруп \\ Черноморский технический университет, Туриия \\ *e-mail:mkurnaz@ktu.edu.tr
}

\begin{abstract}
Mertensiella caucasica - уязвимый вид, распространенный на ограниченной площади от юга Грузии до северо-востока Турции. Статья содержит данные о пяти новых местонахождениях вида из провинции Гюмюшхане (Турция), расширяющих ареал вида на 40 км к югу. Мы определили потенциальное распространение вида в данном регионе Турции. Мы прогнозируем сокращение среды обитания M. caucasica в будущем. И местонахождения на границе ареала, подобные выявленным нами, будут важны для понимания толерантности вида.
\end{abstract}

Ключевые слова: кавказская саламандра, наиболее южное местонахождение, переменная среды, потенциальное распределение, предпочтение среды обитания, расширение ареала 